\title{
Courting Reversal: The Supervisory Role of State Supreme Courts*
}

The most important function of state supreme courts is to supervise lower courts. ${ }^{1}$ Yet surprisingly little has been written about the supervisory process. ${ }^{2}$ Nor is there much literature concerning reversal, the

- The data for this Note were collected by Bliss Cartwright, University of Virginia, Robert A. Kagan, University of California, Berkeley, Lawrence M. Friedman, Stanford University, and Stanton Wheeler, Yale University, under N.S.F. Grant GS-384-13, and were made available to the author as a member of a Yale Law School seminar conducted by Stanton Wheeler. The author wishes to thank them for the use of the data and for their valuable comments and suggestions. The responsibility for opinions expressed in this Note is the author's alone; they do not necessarily reflect the conclusions and interpretations of the project investigators. Their study is hereinafter referred to as SSC Project without additional citation.

For an article based on the same data set, see Kagan, Cartwright, Friedman \& Wheeler, The Business of State Supreme Courts, 1870-1970, 30 STAN. L. REv. 121 (1977).

1. This supervisory function has several components: clarifying state law, articulating policy, and insuring that trials are fairly conducted and that substantive justice is achieved. These aspects of appellate court decisionmaking have been recognized in the literature. E.g., D. Meidor, Appellate Courts 2-3 (1974); Parker, Improving Appellate Methods, 25 N.Y.U.L. REv. 1 (1950). These are tasks that the supreme courts accomplish primarily through their review of appealed decisions. See note 17 infra.

State law requires clarification when different lower courts in the state reach different results on similar fact situations. The law is uncertain until a party appeals and the supreme court declares which of the conflicting lower court interpretations is to be the law of the state. Supreme courts articulate policy when they interpret laws and regulations that legislatures and agencies have made, and when they adjust the common law to contemporary society. Such policymaking activities are undertaken within the framework of supreme court review of lower court decisions. Supreme courts also set the rules for the conduct of fair trials by deciding what "fairness" is and how specific incidents at trial and actions or omissions of the lower court judges affect fairness. Again, the supreme courts do this in their role as supervisors of lower courts. Any of the three functions may be fulfilled in a single decision. See generally ABA, Standards Relating to Appeliate CourTs $\$ \$$ 3.00-3.11 \& Commentary (Approved Draft 1977) [hereinafter cited as ABA Standards]; P. Carrington, D. Meador \& M. Rosenberg, Justice on Appeal 1-12 (1976); R. Leflar, Appellate Judicial Opinions (1974); Shapiro, Courts, in Governmental InstituTIONS AND Processes 357-62 (F. Greenstein \& N. Polsby eds. 1976).

2. Even the classic works on the appellate process neglect the supervisory role. Karl Llewellyn referred to the "corrective function of appellate judging," but as it applies to the bar, not to lower courts. K. Llewellyn, The Common Law Tradition 291 (1960). He also referred to the "pat or slap of affirmance or reversal" as steadying the work of an intermediate appellate court judge and making him more accountable for his work product, $i d$. at 47 . Jerome Frank mentioned supervision by upper courts only to call "fallacious" the notion that "legal rules, supervised by the upper courts, control decisions." J. Frank, Courts on Trial 222 (1950). See B. Cardozo, The Nature of the Judiciar. Process (1921) (no mention of lower courts); Leflar, Some Observations Concerning Judicial Opinions, 6l Colum. L. Rev. 810, 813-14 (1961) (listing nine audiences for appellate opinions; lower court judges not included). For an examination of supervision by the United States Supreme Court of the federal court hierarchy, sce W. MurPhy, ELEMENTs of Judicial Stritegy 91-122 (1964) (Supreme Court use of command, persuasion, personal esteem, sanctions, bargaining, and possible appointment influcnce in effecting lower court acquiescence in policy determinations). 
primary medium of supervisory communication between supreme courts and lower courts. To some extent, this may simply reflect the means of study traditionally employed. The usual techniques used by scholars to examine the work of appellate courts are scrutiny of a limited number of exceptional cases, ${ }^{3}$ study of a particular court, ${ }^{4}$ or analysis of the decisionmaking process. ${ }^{5}$ Few writers have undertaken an empirical investigation of the day-to-day business of state supreme courts. ${ }^{6}$ Moreover, any kind of statistical analysis of a large, carefully collected base of aggregate data is lacking.

This Note takes a first step in the direction of a rigorous description of how state supreme courts function in supervising lower courts. It examines the nature of the judicial supervisory role through an analysis of the frequency with which state supreme courts reverse lower courts. Part I discusses supreme court supervision and the role of reversal in the judicial supervisory process. Part II describes the methodology of the study. Part III sets out hypotheses about the effect of particular variables on the rate of reversal and reports whether these hypotheses

3. See Canon, Organizational Contumacy in the Transmission of Judicial Policies: The Mapp, Escobedo, Miranda and Gault Cases, 20 ViL. L. REv. 50 (1974) (analysis of state supreme court references to and use of United States Supreme Court decisions).

4. See Beiser, The Rhode Island Supreme Court: $A$ IVell-Integrated Political System, 8 LAw \& Soc'Y REv. 167 (1973) (interviews with supreme court judges and analysis of cases between December 1964 and October 1967); Fair, An Experimental Applicalion of Scalogram Analysis to State Supreme Court Decisions, 1967 Wis. L. Rev. 449 (quan. titative analysis of judicial voting behavior in Pennsylvania Supreme Court decisions); Smith, An Historical Sketch of Oregon's Supreme Court, 55 ORE. L. REv. 85, 97 (1976) (concluding "only meaningful measure" of judicial performance is "analysis of . . . decisions"). Beiser found very little public disagreement, as expressed in dissenting opinions, among the judges of the Rhode Island Supreme Court because of their consensus as to the court's function and how to fulfill it.

5. Llewellyn dealt with the style of opinion writing as it reflects appellate decisionmaking; he viewed accountability as a guiding force in the decision process. $K$. LlewEllyN, supra note 2. In a perceptive study of the Second Circuit, Marvin Schick offered an informative description of the mechanics of the decisionmaking process as well as the interrelationships involved. M. Schick, Learned Hand's Court 73-122 (1970). See Smith, The Appellate Decisional Conference, 28 ARK. L. REv. 425 (1975) (importance to decisionmaking process of conference among judges hearing particular case in state supreme courts).

6. The most comprehensive study of state supreme courts undertaken to date is the SSC Project. Previous studies include H. Glick \& K. VINEs, STATE CourT SYstems (1973); Adamany, The Party Variable in Judges' Voting: Conceptual Notes and a Case Study, 63 AM. Politicat Scr. Rev. 57 (1969); Canon \& Jaros, External Variables, Institutional Structure and Dissent in Stale Supreme Courts, 3 PouIry 175 (1970); Canon \& Jaros, State Supreme Courts-Some Comparative Data, 42 ST. Gov'т 260 (1969). For other, more limited investigations, see Baum, Decisions to Grant and Deny Hearings in the California Supreme Court: Patterns in Court and Individual Behavior, 16 SANTA CLARA L. Rev. 713 (I976) (statistical study of use of discretion to review in California; covering only 1972 and 1974); Note, To Hear or Not to Hear: A Question for the California Supreme Court, 3 STAN. L. REv. 243 (1951) (study of factors affecting supreme court's decision to grant hearing; analyzing 457 cases). 
were supported by the data. Finally, Part IV summarizes the findings and describes two themes pertaining to the supervisory role that emerged from the study: the case-screening process prior to appellate review plays an important role in the supervisory process, and complex cases require more supervision.

\section{The Supervisory Role of State Supreme Courts}

\section{A. Appellate Review as a Type of Hierarchical Supervision}

In the judicial hierarchy, state supreme courts are charged with the task of supervising their administrative subordinates-the lower courts. In this respect, judicial supervision resembles the supervision that takes place in other large organizations. But judicial supervision is unique in the severe constraints placed on communication between supervisor and subordinate and in the scope of review that supreme court judges can exercise. ${ }^{7}$

Judicial supervisors, unlike the typical bureaucratic superior, cannot initiate review of their subordinates' work; the work of lower courts is examined only when a litigant appeals a decision. ${ }^{8}$ State supreme courts must also contend with legal limits-either in the common law, constitution, or statutes of the particular state-on the type of questions over which they can exercise supervision. ${ }^{9}$ Most states allocate considerable discretion to trial courts in deciding certain types of issues; $;^{10}$ when the

7. Canon, supra note 3, at 54, points out some of these differences. For a classic discussion of bureaucratic hierarchy, see M. Weber, Bureaucracy, in From MAx Weber: Essays in Sociolocy 196 (H. Gerth \& C. Mills eds. 1946).

8. E.g., Hazard, After the Trial Court-the Realities of Appellate Review, in THE Courts, the Public, aNd the Law Explosion 60, 66-67 (H. Jones ed. 1965). See also Black, The Mobilization of Law, 2 J. Legat Srud. 125, 128 (1973) (entire legal process subject to initiative of citizens and parties; process "reactive").

9. Particularly if the court has discretion to review, there may be constitutional limits on the types of cases it can hear. For example, the Florida Supreme Court's certiorari review is limited to three classes of cases: 1) those affecting a class of constitutional rights or state officers, 2) those passing on questions certified by the district court of appeal (an intermediate appellate court) to deal with questions of great public importance, and 3) those representing direct conflict among the intermediate courts in the state on the same question of law, or with a prior supreme court decision. FLA. Const. art. 5, $\S 3(\mathrm{~b})(3)$.

10. For a discussion of discretion as a review-restraining concept, see Rosenberg, Judicial Discretion of the Trial Court, Viewed From Above, 22 SYRAcuse L. REv, 635, 64350 (1971). Cf. Pound, Discretion, Dispensation and Mitigation: The Problem of the Individual Special Case, 35 N.Y.U.L. REv. 925, 929 (1960) (judges deciding child custody cases should be allowed more discretion than other trial court judges). In addition, fact-finding by appellate courts is severely limited in almost every state, although findings of fact are not totally immune from review. See, e.g., Carrington, The Power of District Judges and the Responsibility of Courts of Appeals, 3 GA. L. REv. 507, 517-27 (1969).

The scope of review may be circumscribed by statutory or common law "blinder" rules that prevent the supreme court from looking at the trial record. E.g., ALA. R. APP. P. $39(k)$ (state supreme court ordinarily restricted to facts stated in lower court opinion). 
harmless error doctrine is applied, the decision of the judicial subordinate may stand unless the error is very serious. ${ }^{11}$

Judicial subordinates, moreover, are constrained in their ability to communicate with their supervisors. Unlike the typical employee in a bureaucratic organization, lower court judges cannot go to their stperiors for advice on how to handle a problem case. ${ }^{12}$ They must complete the task before them and wait for review, which will be forthcoming only if one of the parties appeals after final judgment. ${ }^{13}$ In addition, there is no face-to-face communication between judicial superiors and subordinates about official duties. Appellate court supervisory directives and criticism are not communicated directly and privately; rather, they are given general publication. The formality of this communication can lead to confusion about meaning, and the lower court cannot ask directly for clarification. ${ }^{14}$ Finally, unlike bureaucratic supervisors, judicial superiors usually do not control hiring, firing, and promotion of lower court judges.

Because of these rules and institutional constraints, the opportunities available to state supreme courts to monitor the work of lower courts are severely circumscribed. Undoubtedly, these limits on judicial supervision make the task of appellate courts more difficult and act to increase the probability of lower court error resulting from misinterpreta-

11. The harmless error rule prevents reversal on the basis of trial court errors that the appellate court holds have not affected the outcome. The doctrine has a tortured history, traced in R. TRAynor, The RIDDLe of HARMLEss ERror (1970). Justice Traynor proposed a "rational harmless error rule" that would allow affirmance if the error did not substantially affect the outcome or did not prevent the jury from reaching its decision in light of all the facts and proper instructions on the law. Id. at 58; Traynor, Some Open Questions on the Work of State Appellate Courts, 24 U. CHI. L. REv. 211, 219-23 (1957). See also Kornstein, A Bayesian Model of Harmless Error, 5 J. LEGaL STud. 121 (1976) (proposing mathematical model for deternining if error was harmless); Note, People $v$. Crimmins: The New Prejudice Rule, 40 ALB. L. REv. 405 (1976) (attacking recent broadening of harmless error doctrine in New York as threatening substantive justice).

The harmless error doctrine, which varies from state to state, may well be a significant factor in reversal rates. Unfortunately, the data set used in this study does not contain a harmless error variable, due to the lack of clarity in opinions as to whether the doctrine was being applied.

12. Certification of a decision to an appellate court indicates to the higher court that the lower court wants help with that decision. This normally does not occur, however, until the lower court reaches some final decision.

13. Hazard, supra note 8, at 68-69. In Maine, however, the trial judge can send issues of law "on report" to the supreme court before entering final judgment. ME. REv. STAT. ANN. tit. 4, $\$ 57$ (West Supp. 1973).

14. Jerome Frank suggested that trial court performance would improve if there were a reduction of the "formality of appeals by permitting the trial judge to sit with the upper court on an appeal from his decision, but without a vote." J. Frank, supra note 2, at 423 . The result of such participation would presumably be better understanding on the part of lower court judges of the reasons for high court disposition of their cases, and increased ability to anticipate the supreme court's reaction to new issues. There may be face-to-face communication if the supreme court justices occasionally "ride circuit" and sit in lower courts, WV. MURPHY, supra note 2, at 106-07. 
tions of supreme court decisions or failure to guess the high court's reaction to new problems. Some of these errors will go undetected and uncorrected, and consequently they will be repeated in future cases.

\section{B. Reversal and the Correction of Lower Court Error}

Supreme court reversal of lower court decisions serves several functions in the judicial supervisory process. In one sense, reversal is a sanction for lower court error-the only penalty that judges suffer for failing to decide cases properly. ${ }^{15}$ Yet reversal is a mild punishment for an individual judge. The primary importance of reversal is in regulating the judicial process. In an individual case, reversal ensures that the outcome is consistent with the outcome in similar cases, with recent changes in the law, or with the supreme court's notions of justice. Reversal, furthermore, "makes law." The outcome in the case at bar creates a paradigm for deciding future cases. ${ }^{16}$

Supreme court reversal is not the only tool for judicial supervision. ${ }^{17}$

15. The reference here is to errors in trials or mistakes of law in opinions. It is recognized that reversal is a blow to the judicial ego and places a slight blemish on the judge's professional track record. R. LEFLAR, supra note 1, at 82; W. MURPHY, supra note 2, at 104-05 (reversal more effective if accompanied by scathing sarcasm directed at lower court); M. Schick, supra note 5, at 133-38. Other, less consequential, avenues for supervision include recall by the electorate, e.g., N.Y. Times, Sept. 8, 1977, at 18, col. 4 (Wisconsin Judge Archie Simonson lost recall election because of remarks in rape case), and impeachment or censure for misconduct, e.g., N.Y. Times, July 17, 1977, at 25, col. 1; id., July 29, 1977, $\S \mathrm{B}$, at 3 , col. I (Judge Jacob Fuchsberg investigated for purchase of New York City notes when it was public knowledge that case on city's finances would come to New York Court of Appeals).

16. See, e.g., B. Cardozo, supra note 2, at 21.

17. An affirmance approves the work of the lower court and may be used to clarify earlier opinions or confused areas of law. Some affirmances function as reversals; they correct an error made by the lower courts, but because the appellate court sees the error as harmless, or not "fundamental," it leaves the decision below undisturbed. In other cases in which the lower court reached the right result using the wrong reasons, the appellate court may educate the lower court without invoking the reversal sanction.

Commentators on the means of reducing judicial workloads suggest that affirmances should not produce opinions cxcept in special circumstances. See, e.g., Advisory CouvciL of Appellate Justice, Standards for Publication of Judicial Opinions (1973), reprinted in R. LEFLAR, supra note 1, at 315-19; Winslow, The Courts and the Papermills, 10 ILL. L. REv. 157, 161 (1915). This suggestion misses the importance of using affirmances to educate lower court judges on the right reasons for their correct decisions. See Bazelon, New Gods for Old: "Efficient" Courls in a Democratic Society, 46 N.Y.U.L. REv. 653, 662 (1971) (written opinions needed to inform lower courts of reasons for affirmance or reversal).

This Note does not discuss original proceedings in the supreme court for mandamus, prohibition, injunction, and similar remedies that have a supervisory effect on lower courts. For a discussion of the use of extraordinary writs to control discretionary action of lower courts, see Wright, The Doubtful Omniscience of Appellate Courts, 41 MINN, L. REv. 751, 771-78, 782 (1957) ("appellate tampering with the work of the trial courts" should be kept to minimum). But see Carrington, supra note 10, at 508-17 (extraordinary writs needed to obtain "timely and effective review" of important rulings). Supervision may also occur through statewide judicial conferences. 
Nevertheless, reversal is central to the supervisory role of the state supreme courts. ${ }^{18} \mathrm{~A}$ reversal is a far more decisive repudiation of a lower court's reasoning or conduct than a statement of disapproval in an affirming opinion that upholds the result of the lower court's decision. ${ }^{19}$ In addition, supreme court decisions accompanying reversals contain more supervisory information for lower courts, a fact supported by several findings of this study: the rate of reversal was directly related to the length of the majority opinion, ${ }^{20}$ to the amount of dissension within the court, ${ }^{21}$ and to the number and type of citations in the opinion. ${ }^{22}$ The rate of reversal, therefore, has been adopted by this study as a convenient index of the level of high court supervision.

\section{Methodology of the Study}

The data set used for this study was collected by other researchers. ${ }^{23}$ It includes approximately 6,000 state supreme court cases selected from sixteen representative sample states. The sample cases cover a 100-year period. ${ }^{24}$ Each case was coded according to forty-two variables, in-

18. Explanations for reversing decisions are a necessary element of fairness to lower court judges: "[e]ven where the final judgment can be rendered on appeal so that no guidance to the trial judge is needed for his use on remand, it is too much a reproof to the judge to reverse his decision without stating reasons." Carrington, Crowded Dockets and the Courts of Appeals: The Threat to the Function of Review and the National Law, 82 Harv. L. Rev. 542, 559 (1969).

19. In fact, the rule that dictum cannot be used as authority means that an affirmance with disapproval of lower court reasoning or conduct carries less authority than the supervision that accompanies reversal.

20. A one page majority opinion was least likely to be a reversal $(27.7 \%, N=202$, significant at .001 ), while an opinion over 15 pages was most likely to be a reversal $(52.5 \%, N=158$, significant at .001$)$. For an explanation of significance, see note 31 infra,

21. See app., Table 9 infra.

22. Cases heavily laden with citations were likely to be reversals. In addition, citations to "legal writings"-treatises, hornbooks, or law journal articles-were likely to be in a reversal. Cases citing no legal writings $(N=2172)$ had a reversal rate of $36.4 \%$, while those citing legal writings had a reversal rate of $41.0 \%(N=1834)$. Both of these are significantly different from $38.5 \%$, the aggregate rate of reversal, at a significance level of .05 or better. Opinions citing law journal articles and out-of-state cases had higher reversal rates than those that did not (the reversal rate for cases citing law journal articles was $51.4 \%$; for out-of-state citations the reversal rate was $41.3 \%$ ).

23. For a detailed description of the sampling techniques for states and cases, coding, cleaning process, recoding, and other technical information about the data, see Kagan, Cartwright, Friedman \& Wheeler, supra note *, at 124-28.

24. The sample period was from 1870 to and including 1970. The sample of cases included 18 cases randomly selected from every fifth year of the published reports of each of 16 state supreme courts, for a total of approximately 6,000 cases (South Dakota and Idaho, two sample states, were not states for the first four sample years). The 16 sample states were selected as representative of the 48 continental states with respect to demographic characteristics and legal structures, such as type of courts within the states. The sample states were Alabama, California, Idaho, Illinois, Kansas, Maine, Michigan, Minnesota, Nevada, New Jersey, North Carolina, Oregon, Rhode Island, South Dakota, Tennessee, and West Virginia. 
cluding the nature of the parties, the procedural history of the case, the types of legal issues involved, and the outcome. ${ }^{25}$ The Note's study of reversal excluded cases that were affirmed in part and reversed in part. ${ }^{26}$

Initial research ${ }^{2 \tau}$ into state supreme court supervision of lower courts led to hypotheses predicting how different types of variables would affect reversal rates. ${ }^{28}$ This study directly tested two types of variables: "institutional" and "case-related." An institutional variable is a characteristic of the judicial system, such as the presence or absence of an intermediate appellate court. A case-related variable is a characteristic of a particular case, such as the occupation of the appellant or the area of law involved. A third type of variable includes the socioeconomic, or "demographic," characteristics of the state in which the case arose; these variables include population, the literacy rate, and per capita income. Unlike the other types of variables, the direct effect of demographic variables on the reversal rate could not be tested with the data set available to the author because they were not set up as independent variables. Instead, they were used to group the states into clusters of demographically similar states. ${ }^{29}$

The hypotheses were tested by comparing the aggregate rate of reversal to the reversal rate of cases grouped according to the variable involved in each hypothesis. To obtain the aggregate rate of reversal

25. Subsequently, some adjustments in the coding were made, such as creation of a separate area-of-law category for collection cases,

26. Approximately six percent of the sample cases were neither affirmed nor reversed in toto, but were affirmed in part, modified, or reversed in part. A tiny fraction, $.2 \%$, were original actions in the supreme courts. Clearly, these other cases contain much supervisory information for the lower courts. Likewise, they can be expected to be cases with several issues, if not complex problems. Since they are so few in number, however, it is probably safe to assume that their exclusion does not seriously affect the findings. The total sample for this Note's analysis was 5,113 cases.

27. This research consisted of general readings on appellate courts, while additional background for the formulation of hypotheses for this study came from discussion at the Yale Law School in the seminar, "History of State Supreme Courts," conducted by Professor Stanton Wheeler in the fall and spring of 1976-1977. The specific hypotheses tested in this study, however, were formulated by the author.

28. An hypothesis can be "a statement about a future event, or an event the outcome of which is unknown at the time of the prediction, set forth in such a way that it can be rejected," H. Blalock, Social Statistics 111 (2d ed. 1960), or a theoretical proposition that has a remote possibility of being indirectly tested, $i d$. at 110 . Occasionally the two become mixed, but an attempt was made in this study to use only the former. For a basic discussion of hypothesis formulation and testing, see id. at 110-15, 155-66.

These hypotheses were buttressed with possible explanations for the expectations, some of which were suggested by literature. The explanations are offered to enlighten the reader as to the reasoning behind the hypotheses. Support in the findings for the hypothesis does not necessarily constitute support for the proposed explanation. Discussion of the importance of separating hypotheses from diffuse interpretation is found in $R$. Merton, Social Theory and Social Structure 100 (enlarged ed. 1965).

29. See pp. 1210-11 infra. The investigators did collect data that included socioeconomic variables as independent variables. 
for all the cases, the number of cases that were reversed was divided by the total number of cases. ${ }^{30}$ The variation of each reversal rate from the aggregate rate was then tested for significance. If the variation was found to be statistically significant, the hypothesis regarding the effect of that variable was considered to be supported. ${ }^{31}$ The decision to accept or reject a hypothesis led to a conclusion about a characteristic of reversed cases. These conclusions in turn suggested the conditions under which state supreme courts are likely to exercise their corrective supervisory powers.

30. The results were as follows:

\begin{tabular}{lrr} 
Affirmed & 3146 & $61.5 \%$ \\
Reversed & 1967 & $38.5 \%$ \\
\cline { 2 - 3 } & $\frac{5113}{100.0 \%}$
\end{tabular}

Over a 100-year period, in 5,113 cases, the highest courts of 16 states reversed the lower courts $38.5 \%$ of the time.

31. Differences between two variables can be chance occurrences. If a result is "significant" at the .05 level, this means that the probability of its occurring by chance is five percent or less. By statistical convention the .05 significance level is one of the classic dividing points at which one is led to reject the hypothesis that the observed difference is an artifact of random sampling, and at which one can assume that a similar result will occur with another set of randomly selected cases. For a detailed explanation of statistical significance, see H. BLALock, supra note 28, at 159-65.

In this study reversal rates were examined for a statistically significant difference from $38.5 \%$ using customary $Z$ scores evaluated under a normal approximation. H. BLALock, supra note 28, at 195 (formula); id. at 196-97 (example); id. at 558 (areas under normal curve). The $N$ used for the computations and referred to in the tables and footnotes is the number of cases coded for the particular variable. For example, if 500 cases came to the supreme court from intermediate appellate courts (IACs), 300 of which were affirmed and 200 reversed, the $N$ would be 500. See app. infra for $N$ values actually used. If the reversal rate for a particular variable was not significantly different from $38.5 \%$ (at a significance level of .05), the null hypothesis (which is that the difference occurred by chance) could not be rejected. In these cases, the hypothesis that the particular variable affected reversal rates was not supported by the data. The converse, however, need not be true: statistical significance of a test result does not prove the hypothesis. There may be alternative, untested hypotheses that would explain the result as well or better. A significant result, therefore, enables the researcher to say only that the hypothesis has not been disproved.

The ceteris paribus assumption underlying the tables and the significance tests may be strained. For example, a test involving one variable does not control for the influence of all other variables, and a multiple regression or correlation analysis would be indicated. See generally E. TuFte, Data ANalysis for Politics ANd Policy 135.63 (1974). Development of such a model could be a next step in dealing with this data. This would be done using each variable shown to have some significant effect on reversal rates, with extensive use of dichotomous or polychotomous variables (because of the nonnumerical, noninterval nature of most of the data) along the lines suggested in Harrison, Education and Underemployment in the Urban Ghetto, 62 AM. Econ. Rev. 796 (1972). For examples of this type of analysis applied to legal problems, see Ehrlich, The Deterrent Effect of Capital Punishment: A Question of Life and Death, 65 AM. EcoN. REv. 397 (1975); Forst, The Deterrent Effect of Capital Punishment: A Cross-State Analysis of the 1960's, 61 MinN. L. REv. 743 (1977). It is not obvious, however, that linear models are correct for this type of data, and it might in any case be difficult to obtain significant regression coefficients. With the large amounts of aggregate data involved in this study, the simple methodology employed here is satisfactory. 


\section{How Supervision Is Exercised}

\section{A. Aggregate Rate of Reversal}

The aggregate rate of reversal cannot reveal very much about how supreme courts exercise their supervisory powers; too many factors blend into the judicial process to make this overall rate very illuminating. The limitations on supreme court supervision, for example, restrict the circumstances in which reversal can occur and thus militate in favor of a low rate of reversal. ${ }^{32}$ But other factors more than counterbalance this effect. The very formality of the judicial process retards communication between judicial supervisors and subordinates and may actually increase the rate of lower court error. More important, the rate of reversal may be increased because the losing party to the litigation makes the decision to appeal. A party who does not have a high estimate of the chances for success would not be expected to appeal. ${ }^{33}$

In this study, the aggregate rate of reversal served as the standard against which the rates for particular variables were compared. The

32. See pp. 1193.94 supra. Although the specific limitations vary among different states, appellate courts generally assume that the trial was properly conducted and that the judge properly exercised his or her discretion and maintained control of the proceedings. See ABA STandards, supra note 1 , at $\$ 3.11$, Commentary; Rosenberg, supra note 10, at 663-65. The charge to the jury, around which many appeals center, is often deemed correct if a reasonable interpretation of its language would sustain the charge. See, e.g., Molloy v. Mitchell, 223 Ala. 666, 668, 137 So. 896, 897 (1931) ("We cannot assume that the jury would accord the charge a meaning different from its plain language."); Elliott $v$. Landon, 89 Ariz. 355, 357, 362 P.2d 733, 735 (1961) (presumption that jurors "correctly applied the instructions of the court"); Zuckerman v. Underwriters at Lloyd's, 42 Cal. $2 \mathrm{~d} 460,478-79,267$ P.2d 777,788 (1954) ("It must be assumed that the jury understood the instructions and correctly applied them to the evidence.") Other presumptions favor findings of fact made below. As one California court explained:

the appellate function is to consider not the relative weight of conflicting evidence but only the legal sufficiency of the record to sustain the findings. Where different inferences might fairly and reasonably be deduced from the evidence, the choice made by the trial court, in the absence of an abuse of discretion, is binding on the appeal. Medico-Dental Building Co. v. Horton \& Converse, 21 Cal. 2d 411, 436-37, 132 P.2d 457. 471 (1942) (citations omitted). See also Claborne v. Nichols, 204 Ala. 282, 283, 85 So. 415, 416 (1920) ("conclusion of [trial] court will not be disturbed unless it is plainly contrary to the great weight of the evidence"); Whitehurst v. State, 106 Fla. 789, 144 So. 61 (1932) (same); Wynekoop v. Wynekoop, 407 Ill. 219, 95 N.E.2d 457 (1950) (same). Jerome Frank, however, has warned that it is a dangerous myth that upper courts "can and will safeguard litigants against the trial judge's mistakes concerning the facts." J. Frank, supra note 2, at 223. If the record is incomplete, the presumption is that the missing parts contain the evidence to support the findings.

33. For a discussion of decisionmaking by the parties to litigation, see Galanter, Why the "Haves" Come Out Ahead: Speculations on the Limits of Legal Change, 9 LAw \&. Soc'Y REv. 95, 97-102 (1974). In civil cases, the possibility of settlement further reduces the chance that a case that is not evenly balanced will last through an appellate hearing. Unless both sides believe that the odds favoring success are high, the weaker party will probably settle. Id. at 101 . On the other hand, if the stakes of the case are high, as in criminal cases, if large money damages are involved, or if an organization is willing to take a chance on losing in the hopes of changing a principle of law in its favor, an appeal may be taken even when the chances of success are low. Id. at 102 \& n.19. 
mean reversal rate for all cases in this study was $38.5 \%{ }^{34}$ Variation from $38.5 \%$ was a signal that a variable had an effect on the reversal rate. If the variation was in the predicted direction and was statistically significant, the data provided support for the research hypothesis.

\section{B. Institutional Variables}

An institutional variable is a characteristic of the judicial system that affects how all cases, or a defined class of cases, are processed. The institutional variables considered in this study were the presence or absence of a judicial right to choose cases to review, the presence or absence of intermediate appellate courts, and the extent of the supreme court's caseload. ${ }^{35}$

\section{Judicial Discretion to Review}

The research hypothesis anticipated that the right of supreme courts to exercise discretion in accepting appeals would significantly affect the rate of reversal. When the supreme court must hear cases by right, the rate of reversal should be lower than when the court may choose the cases it will hear. ${ }^{36}$ Cases heard at the discretion of the high courts were screened by those courts and met the criteria for review in their particular states. For states with intermediate appellate courts, usual grounds for certiorari review include a novel or difficult question, conflict within the state's courts, and the importance of the case in the general public interest. ${ }^{37}$ If the state does not have an intermediate appellate court system, the standards for review are much broader. ${ }^{38}$

34. See note 30 supra. Breaking the 100-year time period into three shows that the mean rate has declined somewhat, but has remained stable over the last two periods. For 18701900 , the rate was $45.2 \%$; for $1905-1935,37.7 \%$; and for $1940-1970,37.7 \%$.

35. Another institutional variable, not examined in this Note, is the existence of specialized courts, such as probate, family, traffic, and tax courts. If such specialty courts are less competent, they will make more errors, require more supervision, and thus be reversed more often than courts of general jurisdiction. On the other hand, higher courts may defer to the expertise of specialized courts, which may lead to a lower reversal rate. The effect of this variable is difficult to determine because of the questionable reliability of variables regarding how many courts intervened between the specialty court and the supreme court.

36. See Cuomo, The New York Court of Appeals: A Practical Perspective, 34 Sr. JoHn's L. REv. 197, 199 n.8 (1960) (many cases appealed as of right would be refused by court if it had right to refuse them).

37. E.g., Fla. Const. art. 5, § 3(b); Kan. STAt. \$ 20-3018 (Supp. 1977); cf. ABA STANDARDS, supra note 1 , at $\$ 3.10$ (recommended standards for review). The new grounds for review by the Kansas Supreme Court include "the need for exercising the supreme court's supervisory authority," KAN. STaT. $\$ 20-3018$ (b)(3) (Supp. 1977).

38. For example, Virginia, a state without an intermediate appellate court, has standards that include review of cases that challenge the constitutionality of a law and cases that involve the life or liberty of any person, VA. ConsT. art. VI, $\$ 1$. This standard for review is expanded by $V_{A}$. CoDE $\$ 8.01-670(1977)$, which sets forth cases that a person may appeal. 
Judicial discretion to review enables the court to avoid hearing cases it considers to be without merit, and accordingly allows the court to grant certiorari in order to reverse an unacceptable lower-court ruling. ${ }^{39}$

The findings support the hypothesis that discretion to screen cases for review is a significant factor in the reversal rate. Appeals as of right were reversed $36.8 \%$ of the time, which is slightly but significantly less than the aggregate rate. For cases heard at the discretion of the court, the rate was $50.0 \% \%^{40}$ Thus judicial discretion to review appears to supplement the decisions of private litigants in weeding out nonmeritorious appeals.

\section{Intermediate Appellate Courts}

According to the research hypothesis based on pre-appeal screening by litigants, presence of an intermediate appellate court (IAC) in the state judicial system should raise the reversal rate. IACs have primary responsibility for review of individual cases and are also responsible for extending the application of developing law within the framework

39. M. ScHICK, supra note 5, at 331-35, discusses the meaning of granting or denying certiorari by the United States Supreme Court vis-à-vis lower federal courts. He considers the rate of reversal to be a measure of the effectiveness and quality of a lower court. See Baum, supra note 6, at 714-15 (footnotes omitted):

much has been learned about the process of case-screening in courts with discretionary jurisdiction. Perhaps the most important finding has been that judges seem to respond to petitions for hearing largely in terms of their assessments of the lowercourt decisions in question; they are much more likely to favor a hearing when they feel that the lower court has erred. At both the federal and state levels, this "monitor policy" is suggested by the high rates of reversal in courts that screen appeals.

See also N.Y. Times, Oct. 3, 1977, at 34, col. 1 (United States Supreme Court reverses 61\% of cases; grants certiorari when it sees error).

40. For appeals as of right, $N=4475$; for discretion cases, $N=636$. Both reversal rates are significantly different from $38.5 \%$ (for appeals as of right, a significance level of .01 ; for discretion, .0001). West Virginia was the only sample state whose supreme court could exercise discretion on all types of appeals, and it had the highest overall reversal rate, $58.1 \%$, which is significant at better than .05 . This finding does not suggest that discretion is the only reason for West Virginia's high reversal rate. For the major portion of the sample period, West Virginia did not have a harmless error rule, and this may have played a significant role in its high rate. The state with the next significantly high reversal rate, North Carolina (43.1\%), did not have discretion in most cases for the period of this study. But all of the significantly low reversing states-Minnesota $(28.8 \%)$, Kansas (31.8\%), and Nevada $(32.3 \%)$-heard all appeals as of right. See app., Table I infra.

The code variable describing whether the case came to the supreme court as of right or by discretion may be unreliable, because unless the case report noted a grant of review, writ of certiorari, or some other indicator of supreme court discretion, the coder was instructed to assume that the case was heard as of right. However, the project investigators have clustered the sample states by the amount of discretion their high courts exercised between 1940 and 1970, R. Kagan, B. Cartwright, L. Friedman \& S. Wheeler, The Evolution of State Supreme Courts (1977) (unpublished manuscript, on file with Yale Law Journal). An analysis of variance test conducted by this author verified that there is a significant relationship between ability to exercise discretion and reversal rates for that time period $(F=4.56$, significant at .03$)$. See app., Table 11 infra; H. BLALocK, supra note 28 , at $317-28$. 
established by the highest state court. ${ }^{41}$ Although they can err in either of these judicial duties, it was assumed that state IACs would ordinarily perform their functions correctly, so the hypothesis that the existence of IACs would raise the reversal rate was not based on the expectation that IACs frequently err.

Pre-appeal screening by litigants was the factor that was expected to raise the reversal rate. Following a final decision by the IAC, several factors weigh against a second appeal. The parties' litigation resources have been drained, and the decision of the trial court has been reviewed for error. Thus it was expected that litigants who appeal from the decision of an IAC must believe even more strongly in their chances of winning at the supreme court level than do litigants who take appeals to the IAC. Moreover, litigants who win at the trial level but lose in the IAC, or who lose at both levels with dissent in the IAC, may have some measure of optimism about their chances at the supreme court level.42

Surprisingly, mere presence or absence of an IAC in the state was not a significant factor affecting reversal rates. State supreme courts reversed IACs in $40.4 \%$ of the cases. For those cases that came directly from a trial court, the rate was $38.6 \% .^{43}$ This difference, although in the predicted direction, is statistically insignificant.

Strikingly, the reversal rate differed dramatically depending on the IAC disposition of the lower court decision. In cases in which the IAC affirmed the lower court, the supreme court reversed the IAC $38.6 \%$ of the time; if the IAC reversed the lower court, the reversal rate was $52.5 \%{ }^{44}$ Thus the supreme courts seem to side with the trial courts, a finding that was not expected and is hard to explain.45

41. ABA Standards, supra note 1 , at $\$ 3.00$, Commentary.

42. See Baum, supra note 6 , at 726 (high acceptance rate of petitions for hearing by California Supreme Court on cases in which there was dissent in IAC).

43. For cases from IACs, $N=240$; the reversal rate was not significantly different from $38.5 \%$. For cases from trial courts, $N=4766$; the reversal rate was not significantly different from $38.5 \%$. However, there were changes over time in reversal rates of cases from IACs. In 1870-1900 the rate was $76 \%$, and for $1940-1970$ the rate was $41 \%$. For closer analysis of the effect of IACs in the sample states, see R. Kagan, B. Cartwright, L. Friedman \& S. Wheeler, supra note 40.

44. When the IAC affirmed the lower court $(N=166)$, the rate was not significantly different from 38.5\%; when the IAC reversed the lower court $(N=59)$, the rate was significant at .01. Baum, supra note 6 , at $724-25$ \& table 6 , found that cases in which the IAC had reversed the lower court were significantly more likely to be accepted for review by the California Supreme Court. See Note, supra note 6, at 257 (fig. 2) (if trial court had been reversed by IAC, supreme court granted review on high percentage of appeal applications). This same study found general disagreement by the supreme court with the IAC ( 55 out of 100 cases), id. at 250-51.

45. IACs may be less willing than supreme courts to defer to trial court discretion. There may be judicial rivalry between the IAC and supreme court levels, causing the 


\section{Court Caseload}

The research hypothesis was that the rate of reversal would be inversely related to the volume of a supreme court's caseload. A court with a heavy docket should have a correspondingly low rate of reversal on the assumption that courts with a large caseload would have little time to spend searching for lower court error in every case. ${ }^{46}$ Also, overloaded supreme courts might hesitate to reverse for fear that to do so would invite more appeals.

The findings, however, gave no support to this hypothesis. Although a few states had high case volume and low reversal rates as predicted, the pattern in most states was inconclusive. Regression analysis also produced no support for the research hypothesis. ${ }^{4 i}$ The data thus showed no evidence that a supreme court's caseload affects the diligence of its supervision of lower courts. ${ }^{48}$

\section{Case-Related Variables}

A case-related variable is a characteristic of the case itself, rather than of the judicial system in which it arises. Such variables include the nature of parties, the complexity of the case, the type of issue or issues involved in the appeal, and the area of law.

\section{Nature of parties}

It was hypothesized that strong parties-parties with access to litigation resources, wealth, and political power-would succeed over weak

supreme courts to reverse IACs to maintain their superiority. More likely, there may simply be more merit to a losing claim at the IAC level when the lower court previously ruled for the litigant. Further, if supreme courts are inclined to reverse but the decision is close, they may be more comfortable reversing the IAG when the lower courts are on their side.

46. See Carrington, supra note 18 , at 555 :

If meritorious cases are being delayed, or receiving too little attention, the conscientious judge must respond to his impulses to cut short his deliberation over matters that seem less promising. As he does so, he is unmistakably transforming the character of his decision and the process by which it is made.

47. Regression analysis of caseload and reversal rates for the 100-year period and for each of three time periods (1870-1900, 1905-1935, 1940-1970) produced very insignificant regression coefficients and regression correlations. Five states supported the hypothesis: Kansas and Minnesota (high volume/low rates); South Dakota, Tennessee, and West Virginia (low volume/high rates). Nevada and Rhode Island had low volume and low rates. Controlling for discretion might show a stronger relationship between reversal rate and caseload. A discussion of these variables is found in R. Kagan, B. Cartwright, $L$. Friedman \& S. Wheeler, supra note 40.

48. This finding is less surprising if one assumes that volume affects court delay, rather than the amount of time spent on a case. For a discussion of the problems created by delay, sce McCormick, Appellate Congestion in Iowa: Dimensions and Remedies, 25 DrAKE L. Rev. 133, 134-35 (1975). 
parties. ${ }^{49}$ To succeed, a party must win reversal as an appellant and win affirmance as a respondent. A test for the types of parties who win and lose in appellate courts ${ }^{50}$ is also a test for bias in favor of powerful parties in the judicial supervisory system. ${ }^{51}$ To function effectively, the adversary system of justice requires a contest between equals; when unequal parties oppose each other, the disparity in power may affect the outcome of the struggle. ${ }^{52}$

It was predicted that wealthy private parties would be more successful litigants than less affluent parties. Wealthy litigants can hire superior counsel and pay the costs of a long appeal. ${ }^{53}$ Although there was no true "wealth" variable in this study, it seems plausible to assume that business organizations are wealthier than natural persons and that banks, insurance companies, and real estate companies (as a single category) are wealthier than small retail trade businesses. The findings support the expectation that wealthier parties win. Business organizations had a slightly higher reversal rate than natural persons. ${ }^{54}$ Of the

49. See Frankel, An Immodest Proposal, N.Y. Times, Dec. 4, 1977, \& 6 (Magazine), at 92 (suggesting reforms of adversary process to alleviate wealth and power imbalance).

50. Galanter, supra note 33, at 97-104, suggests that "haves"-large organizations, the government, big city law firms-come out ahead in the judicial process because they are "repeat players" as opposed to "onc-shoters." He emphasizes the repetition of play as the significant factor. Repeat players cannot be repeat players, however, without the financial resources to be in the forum.

51. This does not imply personal bias on the part of the judges in favor of powerful parties. Galanter, Afterword: Explaining Litigation, 9 LAw \& Soc'Y REv. 347, 360 (1975), notes that "persuasive demonstrations of systematic bias are few and far between" and discards judicial bias as an hypothesis to help explain litigation outcome. Rather, parties with resources to initiate and maintain an expensive appeal may hold out and thereby succeed. Although it would be desirable to control for the influence of wealth and power by excluding all cases where a disparity in wealth or power can be discerned between the appellants and respondents, this would not leave enough cases to examine for other factors influencing the reversal rate.

52. Frankel, supra note 49 , at 96 . The character of counsel and the locale where counsel practices are two variables that might measure the level of resources of the parties. When compared to sole practitioners, firms combine competence and financial resources and would thus be expected to have higher reversal rates as appellants and lower reversal rates as respondents. Large-city firms have the same comparative advantage over small-town firms and would also be expected to enjoy similar success on appeal. To the extent that a combination of in-state counsel with out-of-state counsel indicates power and money, one would expect such combinations to have a favorable reversal rate. As Table 3, app. infra, shows, the government does best on appeal $(N=162$, significant at .02$)$. Outside of government lawyers, only a combination of one or more sole practitioners with a firm does much better than normal. In-state capital city attorneys do well, but this includes government attorneys. It is interesting that in-state, large-city appellants and respondents both have reversal rates of $34.4 \%$ (both significant at .001 ); they lose as appellants and win as respondents more than lawyers from other locations in the state. The large-city category, of course, includes lawyers covering the entire spectrum of competence. Thus this category alone, without controlling for type of firm and client, does not reveal much information.

53. Counterbalancing this positive force on the success rate on appeal of wealthy parties is the observation that wealthy litigants may have more at stake and so may be willing to appeal when the chances of success are less.

54. See app., Table 4 infra. 
types of business organizations represented in the coding, financial institutions, insurance companies, and real estate concerns did best as appellants and respondents, while retail trade businesses did especially poorly as respondents. ${ }^{.5}$

This hypothesis was also tested by examining government appeals. The government was viewed as a strong party. Because of the availability of public resources for litigation, as well as the possibility of judicial bias in favor of a coordinate branch, it was expected that the government would succeed both as an appellant and as a respondent.56 An alternative hypothesis, suggested by the finding in Paul Carrington's study that the government was successful on appeal, ${ }^{57}$ is that the government should be viewed as a "rational appellant." As compared to private litigants, Carrington argued, the government undertakes a more careful and rational evaluation of the chances of success before deciding to appeal. This hypothesis would predict that the government would have better than average success as an appellant but no better than average success as a respondent.

The data support Carrington's hypothesis, not the general research

55. For finance, insurance, and real estate the reversal rate was $42.6 \%(N=324)$ as appellant, $34.4 \%(N=291)$ as respondent. For retail trade the reversal rate was $37.0 \%$ $(N=154)$ as appellant, $52.1 \%(N=117)$ as respondent. All four rates are significant at better than .05 .

56. Hazard, supra note 8 , at 68 (government does well in appeals because it can manipulate cases so that "ones that 'look good' will reach the appeal stage first"); Ulmer, Hintze \& Kirklosky, The Decision to Grant or Deny Certiorari: Further Consideration of Cue Theory, 6 LAw \& Soc'y Rev. 637, 641 (1972) (finding federal government success in winning certiorari petitions); Note, supra note 6, at 258-59 (finding government success in winning California Supreme Court review). But see Baum, supra note 6, at 727-30 (finding no evidence of state government success on appeal). The studies in both Baum, supra note 6 , and Note, supra note 6 , suffer the handicap of inadequate data.

57. Carrington, Uniled States Appeals in Civil Cases: A Field and Statistical Study, 11 Hous. L. REv. 1101 (1974). This study showed a remarkable success rate of United States attorneys in civil appeals. Although the overall success rate of federal civil appellants is about $20 \%$, the United States prevails in $50 \%$ of its appeals. Nongovernmental litigants against the government win about $10 \%$ of their appeals, and taxpayer appellants are less successful than criminal appellants. Referring to the United States Government as "a cautious and successful litigant" at all levels, Carrington attributes this success rate to the process for deciding what cases to appeal. The Solicitor General decides whether to press appeals based on the recommendations of various Justice Department divisions. There is a careful analysis of the principles likely to control the outcome, although occasionally the sheer amount of an award will trigger an appeal. But, as Carrington said, "[w]e know that the adversaries' decisions to appeal are less rational and more speculative than those made by the United States." Id. at 1121. In addition, the government lawyer is not pressured by a litigious client to take a chance on a less meritorious appeal.

At the state government level, where lawyers are notoriously underpaid and thus perhaps less competent as a group, there is nevertheless likely to be similar objective screening of appeals. When Baum, supra note 6 , at 730 , found lack of success by the government in California, he attributed it to his surmise that "the restraint that goes far toward explaining the Solicitor General's success did not exist at the state level, at least during these two periods." 
hypothesis. They indicate that government appellants have a higher reversal rate than natural persons, business persons or professionals, and business organizations. ${ }^{58}$ But the record of government agencies as respondents is only average. ${ }^{59}$

Examination of the rate of success of different governmental bodiesstate, county, large city, small town-as litigants produced only minimal support for the research hypothesis. Within a state it was expected that the success of different governments would be related to their size and implicitly to their wealth and power. The data indicate that state governments had the best success record, ${ }^{60}$ but below the state level there was no correlation between reversal rate and size of governmental body. ${ }^{61}$

\section{Complexity of the Case}

As a research hypothesis, it was predicted that complex cases would have a higher rate of reversal than simple cases. Complex cases, it was thought, would provide more opportunity for lower court error and therefore would call forth more supreme court supervision. Theoretically, a complex case would include a difficult issue, a policy question, a voluminous record, more than one issue, and numerous parties. Unfortunately, there was no coding for case complexity in the study. But several variables were considered rough indicators of complexity: number of parties, mix of party types, existence of a class action, ${ }^{62}$ and amicus participation. ${ }^{63}$ Cases containing these complicating factors were

58. See app., Table 4 infra. The difference is statistically significant at a level of .03 .

59. Id. The government has more success as a respondent when the appeal is a criminal case than when it involves a civil matter. The explanation for this seems to lie in the motivations for criminal defendants to appeal. See notes 78-79 infra.

60. State governments had reversal rates of $46.9 \%$ as appellants and $34.3 \%$ as respondents, both significantly different from the overall rate. See app., Table 5 infra.

61. Id. State governments also do better than municipal governments on review petitions. Note, supra note 6 , at 259.

One would not expect all governmental agencies to do equally well, because they would not all share the same level of legal competence or resources. The reversal rate of tax agencies as appellants was $51.2 \%$ and was statistically significant at .004 . One possible explanation is that tax agency decisions to appeal are most rational; another explanation is that government tax lawyers may be more competent than other government lawyers. $A$ third reason could be that appellate courts are more interested than lower courts in seeing that revenues are collected. If either of the latter two reasons were totally truc, government tax lawyers also would do well as respondents. In fact, as the data show, they had about average success as respondents. This lends credence to the "rational appellant" theory because the respondent does not have control over the cases it must respond to in appellate litigation. As appellant, the government chooses to appeal only those cases it expects to win, and this apparently occurs after a more thorough and objective analysis of the chances of success than is employed by other litigants.

62. Coders did not consider whether the class action was pleaded or certified.

63. Cases that attract participation by "friends of the court" can be expected to involve public policy issues, which makes the cases more difficult to decide than cases turning on pure legal doctrine. Thus the lower courts are likely to make more errors in such 
expected to have higher reversal rates than cases without such complexity indicators.

The findings gave some support to the hypothesis. Reversal rates were directly and significantly related to the number of parties involved $^{64}$ and to the mixture of parties. ${ }^{65}$ The presence of a class action did not raise the rate as expected. ${ }^{\circ 0}$ Although less than one percent of the sample cases had amicus participation, the data lent some support to the prediction that mere presence of an amicus brief for either side is correlated with reversal rates. ${ }^{\circ T}$ It thus appears that complex cases are more likely to be reversed on appeal.

\section{Type of Issue}

Based on the assumption that reversal reflected the degree of difficulty lower courts had in resolving various types of legal issues, it was expected that the type of issue presented on appeal would have an important effect on the reversal rate. There were three choices for coding the type of issues discussed for one or more pages in the opinion: (1) constitutional issues (state, federal, or both), (2) nonconstitutional procedural issues alone, or (3) nonconstitutional substantive issues alone or combined with procedural issues.

It was expected that constitutional issues would be difficult for lower courts and would require more active supervision by the supreme court. ${ }^{68}$ This led to an expectation of a high reversal rate for

cases and to require more supervision. Or, even though the lower court did not err in relation to past instructions, the supreme court may allow itself to be convinced by the appellant to change its position. The supreme court then would reverse, not as a sanction for crror but to educate the lower courts in new policy. Regardless of which side received the benefit of the brief, one would expect the presence of an amicus brief to indicate a difficult policy case. Therefore reversal rates should be higher for these cases.

64. Reversal rates increased as the number of appellants or respondents increased. App., Table 7 infra.

65. A mixed party is a combination of two or more categories of parties, such as a natural person and a business, or a business and a governmental agency. When the appellant was a mixed party the reversal rate was $43.0 \%$; when the respondent was a mixed party, the rate was $42.3 \%$. Both rates are significantly different from $38.5 \%$, the aggregate rate of reversal.

66. The reversal rate for a class as appellant was $30 \%(N=20)$ and was not significant at .05 ; for a class as respondent, the reversal rate was $62.5 \%(N=16)$ and was significant at .01 . The sample is too small to attribute much importance to these findings. But even with only 16 cases, one can say that litigants losing to class actions have a good chance of winning on appeal.

67. Seventy-four cases had amicus briefs, and their reversal rate was $45.9 \%$ (significant at .09).

68. The rationale for assuming that constitutional Iaw cases are difficult was that constitutional doctrine is filtered through both the state and federal judiciaries, potentially increasing the probability for lower court error. It could also be assumed that constitutional law cases are intellectually more difficult than other cases. On the other hand, it is not uncommon for a lawyer with a weak case to throw in any constitutional challenge as a last resort. See ABA Standards, supra note 1 , at $\$ 3.10$, Commentary. 
cases with one or more constitutional issues. ${ }^{69}$ The data did not support the hypothesis. ${ }^{70}$ Mere presence of a constitutional issue in the sample cases did not raise the reversal rate. ${ }^{71}$

There was, however, a suggestive finding concerning the level at which decisions on constitutionality are made. ${ }^{72}$ The data indicate that if a statute or regulation is to be held unconstitutional, it will be done at the supreme court level. Where the supreme court held a challenged statute or regulation unconstitutional, it was reversing at a rate of $68.3 \%$. Where it upheld the statute or regulation as constitutional, the court was reversing lower courts only $17.3 \%$ of the time. ${ }^{33}$ This indicates either an amount of deference to the legislature on the part of lower courts that the supreme courts do not share, or a perception by lower courts that a finding of unconstitutionality belongs in the hands of the supreme courts.

Because it was assumed that procedural questions are likely to be less troublesome to lower courts than are substantive issues, ${ }^{74}$ it was predicted that among nonconstitutional cases procedural-issue cases would have a lower reversal rate. The data did not support this hypothesis. If

69. Cases containing a constitutional issue made up $10 \%$ of the sample. Unfortunately, the coding does not indicate what the gravamen of the case was. Obviously, the court can fill its opinion with supervisory information about constitutional law for the benefit of lower courts while still affirming because another issue is seen as controlling.

70. About $90 \%$ of the cases did not contain a constitutional issue. The reversal rate for these 4,625 cases was $38.8 \%$. For the remaining 488 cases that did involve one or more constitutional questions, the reversal rate was $35.4 \%$. This rate was different from $38.5 \%$ at a significance level of .08 , and that difference was in the wrong direction (to the low side of the mean) to support the hypothesis.

71. Baum, supra note 6 , at 723 , found that presence of a constitutional issue did not affect the California Supreme Court's decision to grant a hearing.

72. If there was a constitutional issue in the case, it was coded according to three possible dispositions by the court: upholding the challenged statute or regulation, declaring it unconstitutional, or discussing it but making no holding. In $43.8 \%$ of the cases the statute or regulation was upheld; in $21.3 \%$ it was declared unconstitutional; in $34.8 \%$ there was no holding after discussion.

73. Both these rates are significant at .0001 . The two extreme reversal rates cancel each other out in the overall rate for all cases with constitutional issues. See app., Table 6 infra.

When the constitutional question was not a challenge to a statute or regulation, it was likely to be a joint state and federal question of either procedural due process or substantive due process. In general, federal constitutional issues provoked fewer reversals than state or joint state and federal constitutional questions. This suggests either that the lower state courts are better versed in federal constitutional law than in state constitutional issues, or that state supreme courts take an especially active role in interpreting state constitutions.

74. Procedural rules and issues seem less open to differing interpretations and mistakes in application than substantive issues. Whereas substantive rules regulate the conduct of the entire society, procedural rules regulate how courts and lawyers must act, and therefore courts can be expected to have greater familiarity with procedural rules. See, e.g., Rosenberg, supra note 10, at 654 (distinguishing between "extremely important issues" and "matters strictly procedural"). These procedural issues should not, however, be confused with constitutional procedural due process. 
the case involved a procedural question alone, lower courts had significantly more trouble avoiding reversal than in cases involving nonconstitutional substantive issues. If the supreme court discussed a procedural issue for one page or more, the reversal rate was $43 \%{ }^{75}$ compared to $38.1 \%$ for substantive-issue cases. ${ }^{76}$

\section{Area of $\mathrm{Law}^{73}$}

The area-of-law variable groups cases according to the governing body of substantive law. Cases in a given area of law may have certain common factual characteristics as well as recurring legal issues. Individual hypotheses were formulated for particular areas of law.

In criminal law cases generally, a low reversal rate was expected. In large part, this was because criminal cases are far more likely to be appealed, regardless of merit. Many of the criminal law cases in the sample were appealed as of right, eliminating the possibility of judicial screening. The stakes are high; criminal appellants have less to lose and will accept a greater risk in deciding to appeal. In addition, the state may pay for the appeal, thus reducing the cost of appeal to the criminal appellant. ${ }^{78}$ In fact, criminal law cases had the lowest reversal rate in the study: $35.6 \%{ }^{79}$ When the remedy sought was habeas

75. The difference from the aggregate reversal rate is significant at $.0002(N=500)$. The explanation for the unexpectedly high reversal rate on pure procedural questions may be that certain procedural doctrines, such as the law of conflicts, are intricate and difficult for Iower courts to apply. For instance, in the present study the procedural questions triggering the highest reversal rate were those coded together in a value covering jurisdiction, venue, and service of process, with a reversal rate for these cases of $47.7 \%$ (significant at .001 ).

76. $N=4155$.

77. See Kagan, Cartwright, Friedman \& Wheeler, supra note *, at 132-52. This variable is closely related to the variable indicating state of origin. Therefore, the true independent effect of each variable on the reversal rate cannot be ascertained without more sophisticated statistical analysis, or without more information concerning how areas of law developed within the states. Even with this caution, however, the aggregate results are of interest.

78. See, e.g., Douglas v. California, 372 U.S. 353 (1963) (appointment of counsel required for indigent state defendant on first appeal as of right). But see Ross v. Moffitt, 417 U.S. 600 (1974) (indigent defendant does not have right to counsel on discretionary review after first appeal). This right to counsel on appeal, however, was not necessarily available in the sample states from 1870 to 1962.

As an example of the willingness of criminal appellants to accept a high risk of failure on appeal, a convicted murderer has the most to gain from a successful appeal, so it is not surprising to find that the reversal rate for murder cases was the lowest of all criminal law cases, $28.8 \%$ (significant at .005).

79. The difference is significant at .057 . See app., Table 8 infra. An additional reason for the low reversal rate may be that criminal law cases are not complex and thus create little difficulty for lower courts. See p. 1210 infra (difficult cases reversed more frequently). A high percentage of criminal law cases are regarded as not complex. III ADvisory Council For APPELLATE JUSTICE: 1975, at 15 (1975). 
corpus, the reversal rate was fourteen percent. ${ }^{80}$

Within the criminal law area, it was predicted that sex crimes and victimless crimes ("crimes against public order or morality") would have higher reversal rates, because they are probably considered under more emotional circumstances in their local jurisdictions and reviewed more objectively by the farther-removed supreme court. Also, such laws are enforced unevenly, which creates disparate results in lower courts. The data show that these two categories of cases do indeed have the highest reversal rates of all criminal law cases. ${ }^{81}$

Relative to the expected degree of difficulty of the area of law for lower courts, it was predicted that cases in real property law would have low or average reversal rates because the legal doctrines are relatively well settled and should require less supervision by the supreme court. ${ }^{82}$ Conversely, it was expected that a new area of law, such as products liability in the tort category, would have high reversal rates. The data supported these hypotheses ${ }^{83}$ Furthermore, within the real property category, the often complex zoning cases had a reversal rate of $54.5 \%{ }^{84}$

Finally, family law cases were expected to have a low reversal rate, because state supreme courts were expected to accord greater deference to the lower courts when dealing with family matters. ${ }^{85}$ Supreme courts were thus not expected to reverse unless the lower court had seriously abused its discretion. The data also supported this hypothesis. ${ }^{86}$

\section{Demographic Variables}

A demographic variable is a socioeconomic characteristic ${ }^{87}$ of the jurisdiction in which the case arises. The study designers used this type

80. $N=50$, significant at .0002 . Habeas corpus petitions are often automatically filed, usually pro se, so there is no input by counsel either on the merits or on presentation of the petition.

81. Sex crimes (excluding rape) had a reversal rate of $51.7 \%$ (significant at .04); crimes against public order or morality had a reversal rate of $42.6 \%$ (significant at .1).

82. See, e.g., McCormick, supra note 48, at 159 .

83. Real property had an average reversal rate. See app., Table 8 infra. Products liability had a reversal rate of $61.8 \%(N=34$, significant at .003$)$.

84. This rate (significant at .06) was for cases that originated in a zoning board. For zoning cases originating in any forum, the reversal rate was $46.7 \%(N=45$, significant at .12).

Insurance law is considered by many to be extremely complex. Insurance cases were coded in the Contract and Commercial category for which the overall reversal rate was $39.4 \%$. The reversal rate for insurance cases was $45.2 \%(N=137$, significant at .05$)$.

85. See Pound, supra note 10 , at 929 .

86. For the 152 family law cases, the reversal rate was $31.8 \%$ (significant at .04 ).

87. The demographic variables considered in this study included:

1) Percent of state population employed in manufacturing;

2) Value added by manufacturing (per capita); 
of variable to cluster ${ }^{88}$ the forty-eight continental states into five groups of demographically similar states. ${ }^{80}$ From these five clusters they selected the representative sample states. ${ }^{90}$ This final sample was intended to provide a basis for drawing inferences about all states; ${ }^{91}$ a conclusion about one state could be assumed to apply to a demographically similar sister state in the same cluster.

The data, however, produced an unanticipated result. As expected, there was wide variation in reversal rates among the sample states. Indeed, the state variable had the widest range in reversal rate values. ${ }^{92}$ Yet the results of a statistical test on the interstate reversal rate varia-

3) Number of employees per manufacturing establishment;

4) Percent urban (living in cities of 2500 or more);

5) Population density (population per square mile);

6) Total population;

7) Rate of population change in previous decade;

8) Per capita income;

9) Value of real property (per capita);

10) Percent black;

11) Percent illiterate (does not exist for 1940);

12) Median school years completed.

SSC Project Proposal, app. A, at 1 (1976) (on filc with Yale Law Journal).

To these data a "legislative innovation" score was added. Walker, The Diffusion of Innovations among the American States, 63 Am. Political ScI. Rev. 880 (1969). This score reflects the date when the state legislature adopted legislative programs (early or late compared to other states) and is used to measure the progressiveness of the state's political tradition and the enactment of new laws that lead to new kinds of lawsuits. See SSC Project Proposal, supra at app. A, at 4.

88. A cluster is a group of states with similar configurations of characteristics. The procedure used was based on a statistical "agglomeration" technique developed by John Hartigan of Yale. See J. Hartigan, Clustering Alcorithms (1975). For a complete description of clustering technique used for this study, see SSC Project Proposal, supra note 87, at 4.8 \& app. $A$.

89. Cluster Onc: Nebraska, Kansas, Iowa, South Dakota, North Dakota, Oklahoma, Vermont; Cluster Two: Ohio, Illinois, New Jersey, Pennsylvania, Michigan, Maryland, Wisconsin, Indiana, Massachusetts, Connecticut, New York, New Hampshire, California, Rhode Island; Cluster Three: Tennessee, Georgia, Alabama, Virginia, Kentucky, North Carolina, Arkansas, West Virginia, Louisiana, Missouri, South Carolina, Texas, Mississippi; Cluster Four: Washington, Oregon, Colorado, Minnesota, Utah, Maine, Florida, Delaware; Cluster Five: Montana, Wyoming, Idaho, Arizona, New Mexico, Nevada.

90. The sample states from the clusters were: Cluster One: Kansas and South Dakota; Cluster Two: Illinois, New Jersey, Michigan, California, and Rhode Island; Cluster Three: Tennessee, Alabama, North Carolina, and West Virginia; Cluster Four: Oregon, Minnesota, and Maine; Cluster Five: Idaho and Nevada.

91. SSC Project Proposal, supra note 87, at 8 . The project designers recognized the limitations on the ability to draw inferences concerning all states. Alaska and Hawaii were excluded altogether. In addition, they noted:

Of course we might expect that some states we do not have would show distinctive characteristics, for example Louisiana, with its civil law tradition, Delaware, with its casier rules for the formation of corporations, perhaps Massachusetts and New York, which most legal historians have regarded as "leading" states with regard [to] doctrinal developments. Id.

92. See app., Table 1 infra. 
tion revealed as much variation within clusters as among them. ${ }^{93}$ In other words, states with similar rates were not in the same clusters of demographically similar states. This finding indicates that demographically similar states do not necessarily have the same reversal rates or similar judicial supervisory processes.

\section{Summary of Findings}

Of the institutional variables, the presence or absence of judicial discretion to review cases for appeal had the most significant effect on reversal rates. Contrary to expectations, presence of an intermediate appellate court in the state court system did not influence reversal rates, nor did the court's caseload.

The case-related variables likewise produced several interesting results. Strong parties-business organizations and the government-did better than natural persons. Complex cases, those with multiple or mixed parties or amicus participation, had high reversal rates. Contrary to expectations, the presence of a constitutional issue did not raise the reversal rate, and for cases without constitutional issues, proceduralissue cases had a higher reversal rate than substantive-issue cases. For the area-of-law variable, several hypotheses were supported by the data: criminal law cases had the lowest reversal rate; sex crimes and victimless crimes had the two highest reversal rates for criminal law cases; real property cases had low reversal rates; products liability cases had a higher reversal rate than other tort cases; and family law cases had low reversal rates. All of these area-of-law findings had been predicted.

Two themes emerge from these findings. First, several of the results suggest that factors that affect the screening of cases before an appeal is heard have a particularly significant impact on the rate of reversal. This theme recurs in the findings related to the appellate court's discretion to review prior to appellate hearing, in the findings that support Carrington's description of the government as a rational appellant, and in the low reversal rates of criminal cases, most of which were heard as of right. The finding that screening cases before appeal is significant

93. The statistical test used was a simple analysis of variance test (ANOVA) on the clusters and reversal rates. It indicated that the variation among clusters could have occurred by chance. The test statistic for the variation among clusters was $F=1.91$; to be significant at the .05 level, the $F$ value should have been 3.36 or greater. An explanation of this test and its relation to research hypotheses is found in H. BLALOcK, supra note 28, at 317-28. 
may be weakened by the inconclusiveness of the data pertaining to the effect of intermediate appellate courts.

The second major theme is that the difficulty of the case affects reversal rates. This is clearly supported by the complexity variables. It is also indicated in the area-of-law data, where products liability and zoning cases are reversed more often than cases involving more settled tort and property doctrines. The "type-of-issue" findings, however, are more ambiguous. Arguably, they also support the proposition that difficult cases are reversed more frequently. That trial courts ordinarily do not find a statute or regulation unconstitutional may mean that they consider the issue beyond their competence. And the results relating to the substantive/procedural issue dichotomy may simply indicate that procedural issues are more difficult.

\section{Conclusion}

Although legal scholars and social scientists appear to take the supervisory function of state supreme courts for granted, no one has yet examined how this role is exercised and the factors that influence it. In studying reversal, the communication medium for the correction of lower court error, this Note has discussed the exercise of judicial supervision and has examined the effect of certain factors on the supervisory process.

Two themes underlie the findings: factors that affect the screening of appeals are an important influence on reversal rates, and the difficulty of the case is significant in affecting reversal rates. States concerned over crowded dockets and the attendant threat to the administration of justice might be well advised to consider reforms that establish discretion for the high court but that also establish grounds for certiorari broad enough to include the cases most likely to contain error. The $A B A$ Standards Relating to Appellate Courts ${ }^{94}$ recommend discretion for supreme courts (at least for states with IACs) and inclusion of "difficult cases" in grounds for appellate review. ${ }^{95}$ Both of these recommendations are supported by this study.

94. ABA STANDARDS, supra note 1 .

95. ABA Standards, supra note 1. The Standards cite both increased caseload and increased case diversity and complexity as requiring reform of appellate court administration. Id. at 1-2. They stress the need for procedures that allow appellate courts to address their attention to complex cases. Necessary to any reform, the Standards assert, is significant discretion on the part of supreme courts to decide which cases to review. Because of the importance of a right of appeal, however, supreme courts in states without IACs 
This Note's findings are only a beginning step into this neglected aspect of the literature on judicial systems and our legal culture. Understanding how this judicial supervisory role is exercised is essential for an appreciation of the operation of the legal system and is necessary background to proposals for reform.

should continue to hear appcals as of right. $I d$. at $\$ \$ 3.00,3.10$, Commentary. For states with IACs, the $A B A$ Standards recommend that a supreme court should grant review only if it determines "that the matter involves a question that is novel or difficult, is the subject of conflicting authoritics applicable within the jurisdiction, or is of importance in the general public interest or in the administration of justice." $I d$. at $\$ 3.10(\mathrm{c})$. The commentary to this section does not discuss what type of cases should be considered "difficult," but it does question allowing review of right merely because the case involves a constitutional issue, a position supported by the findings of this Note, which do not indicate that constitutional questions created significantly greater difficulty for lower courts.

The $A B A$ Standards leave further clarification of what constitutes a difficult case in the hands of supreme court judges. Although detailed recommendations of grounds for certiorari are beyond the scope of this Note, it is clear that lower courts may have particular difficulty in deciding cases that contain complex factors such as multiple and mixed parties, multiple issues, or other questions in new and rapidly evolving areas of law. Grounds for certiorari must set a limit on the cases the supreme court should agree to review, so that the high court can truly supervise lower courts, not merely re-try cases. See Comment, Cerliorari Review of District Court of Appeal Decisions by the Supreme Court of Florida, 28 U. Miamt L. REv. 952, 953 (1974) (since Florida Supreme Court now has discretion to choose cases for review, it "has the duty to act as the supervisory body of the state's judicial system"). Yet if the supreme court is to supervise diligently, rules for certiorari cannot categorically eliminate classes of cases in which lower courts, in the aggregate, have been shown to err seriously.

Some commentators and reformers misunderstand the supervisory function of state supreme courts by applying the phrase "supervisory role" to the role of reviewing only cases involving conflict or "great public interest" or state officers. Commentary, Estab. lishing New Criteria for Conflict Certiorari in Per Curiam District Court Decisions: $A$ First Step Toward a Definition of Power, 29 U. FLA. L. REv. 335, 337 (1977). Supreme courts cannot necessarily assume that justice has been done at the IAC level. See Bazelon, supra note 17 (cautioning against too much efficiency lest reforms create injustice by weeding out too many appeals as frivolous). But see Lake v. Lake, 103 So. $2 d 639,643$ (Fla. 1958) (assuming that IAC gave "earnest, intelligent [and] fearless consideration" to appeal and that justice was done). 
State Supreme Courts

\section{Appendix}

1. Overall Reversal Rate By State

$\begin{array}{lcc}\text { State } & N & \text { Rate } \\ \text { Ala. } & 351 & 38.2 \\ \text { Cal. } & 296 & 40.2 \\ \text { Idaho } & 333 & 35.7 \\ \text { Ill. } & 347 & 38.0 \\ \text { Kan. } & 327 & 31.8^{*} \\ \text { Me. } & 262 & 35.5 \\ \text { Mich. } & 339 & 39.2 \\ \text { Minn. } & 354 & 28.8^{*} \\ \text { Nev. } & 291 & 32.3^{*} \\ \text { N.J. } & 340 & 38.8 \\ \text { N.C. } & 348 & 43.1^{*} \\ \text { Ore. } & 347 & 39.2 \\ \text { R.I. } & 249 & 34.1 \\ \text { S.D. } & 289 & 41.5 \\ \text { Tenn. } & 332 & 40.1 \\ \text { W. Va. } & 308 & 58.1^{*} \\ \text { Total } & 5113 & 38.5\end{array}$

Indicates difference from $38.5 \%$ significant at .05 .

2. Reversal Rate By State Over Three Time Periods

$\begin{array}{lccc} & 1870-1900 & 1905-1935 & 1940-1970 \\ \text { Ala. } & 49.2 & 39.2 & 30.3 \\ \text { Cal. } & 47.7 & 33.9 & 44.2 \\ \text { Idaho } & 49.0 & 39.0 & 31.7 \\ \text { Ill. } & 40.0 & 44.6 & 33.3 \\ \text { Kan. } & 49.1 & 28.3 & 24.8 \\ \text { Me. } & 47.7 & 38.8 & 28.7 \\ \text { Mich. } & 44.6 & 42.9 & 31.7 \\ \text { Minn. } & 28.5 & 24.0 & 38.1 \\ \text { Nev. } & 41.8 & 35.4 & 25.7 \\ \text { N.J. } & 42.6 & 35.7 & 40.5 \\ \text { N.C. } & 46.8 & 35.2 & 47.2 \\ \text { Ore. } & 51.6 & 29.8 & 39.8 \\ \text { R.I. } & 44.1 & 33.3 & 33.3 \\ \text { S.D. } & 35.8 & 45.4 & 40.2 \\ \text { Tenn. } & 50.4 & 42.7 & 40.8 \\ \text { W. Va. } & 52.1 & 54.5 & 67.3 \\ \text { Overall Average } & 45.2 & 37.7 & 37.1\end{array}$


3. Reversal Rates By Type of Counsel

\begin{tabular}{lcrcr} 
Type & Appellant & $N$ & Respondent & \multicolumn{1}{c}{$N$} \\
Sole Practitioner & $37.5 \%$ & 1691 & $39.7 \%$ & 1362 \\
Partnership or firm & $36.5 \%$ & 1327 & $37.5 \%$ & 1289 \\
$\begin{array}{l}\text { Government attorney } \\
\begin{array}{l}\text { More than 1 sole } \\
\quad \text { practitioner }\end{array}\end{array}$ & $46.3 \%$ & 162 & $34.3 \%$ & 746 \\
$\begin{array}{l}\text { Combination of sole prac- } \\
\quad \text { titioner plus firm }\end{array}$ & $38.9 \%$ & 1143 & $38.3 \%$ & 952 \\
& $44.0 \%$ & 675 & $38.8 \%$ & 572
\end{tabular}

4. Reversal Rates By Nature of Parties

$\begin{array}{lcrcr} & \text { Appellant } & N & \text { Respondent } & N \\ \text { Natural person } & 37.2 \% & 2964 & 38.8 \% & 2459 \\ \text { Business person or } & & & & \\ \text { professional } & 38.8 \% & 526 & 43.2 \% & 500 \\ \text { Business organization } & 40.3 \% & 1057 & 37.4 \% & 780 \\ \text { Government } & 42.7 \% & 451 & 37.2 \% & 1251\end{array}$

5. Reversal Rates By Government Domain

\begin{tabular}{lcrcr} 
Domain & Appellant & $N$ & Respondent & \multicolumn{1}{c}{$N$} \\
State & $46.9 \%$ & 130 & $34.3 \%$ & 64.4 \\
Urban County & $39.5 \%$ & 43 & $32.3 \%$ & 96 \\
Other County & $44.3 \%$ & 140 & $43.3 \%$ & 255 \\
Large City & $34.9 \%$ & 43 & $36.4 \%$ & 77 \\
Small City or Town & $40.5 \%$ & 74 & $44.4 \%$ & 124
\end{tabular}

6. Reversal Rate By Court Disposition of Case Containing Challenge to a Statute or Regulation

$\begin{array}{lll} & \text { Rate } & N \\ \begin{array}{l}\text { Upholds statute or regu- } \\ \quad \text { lation }\end{array} & 17.3 \% & 214 \\ \begin{array}{l}\text { Declares statute unconsti- } \\ \text { tutional }\end{array} & 68.3 \% & 104 \\ \text { Discusses, but no holding } & 38.2 \% & 170\end{array}$

7. Reversal Rate By Numbers of Parties

\begin{tabular}{crccrc} 
Appellants & $N$ & Rate & Respondents & \multicolumn{1}{c}{$N$} & Rate \\
1 & 3809 & $38.0 \%$ & 1 & 3821 & $38.3 \%$ \\
2 & 593 & $40.1 \%$ & 2 & 513 & $40.4 \%$ \\
$3-5$ & 191 & $43.4 \%$ & $3-5$ & 185 & $32.4 \%$ \\
$6-10$ & 56 & $44.6 \%$ & $6-10$ & 55 & $41.8 \%$
\end{tabular}


State Supreme Courts

8. Reversal Rate By Major Area of Law

$\begin{array}{lcr} & \text { Rate } & N \\ \text { Criminal } & 35.6 \% & 704 \\ \text { Family \& Estates } & 37.3 \% & 461 \\ \text { Property } & 39.4 \% & 869 \\ \text { Contract, Commercial } & 39.4 \% & 1423 \\ \text { Corporate } & 40.6 \% & 106 \\ \text { Trade \&. Industrial Reg. } & 35.3 \% & 116 \\ \text { Public } & 41.6 \% & 483 \\ \text { Tort } & 37.8 \% & 873\end{array}$

9. Reversal Rates and Unanimity

$\begin{array}{lrr}\text { All unanimous cases (including con- } & 37.4 \% & 4514 \\ \text { All nonunanimous (insent) } & 46.8 \% & 592 \\ \quad \text { currence with no dissent } & 48.8 \% & 451 \\ \text { All cases with at least one dissenter } & 33.6 \% & 128 \\ \text { Unanimous, per curiam } & 37.5 \% & 4386 \\ \text { Unanimous, one opinion } & 40.4 \% & 141 \\ \text { Concurrence with result, no dissent } & 48.8 \% & 209 \\ \text { Majority opinion, one dissent } & 48.4 \% & 184 \\ \text { Majority opinion, 2 or more dissenters } & 54.2 \% & 24 \\ \text { Split majority, I dissent } & 44.1 \% & 34 \\ \text { Split majority, 2 or more dissent } & \end{array}$

10. Reversal Rates By Length of Majority Opinion

$\begin{array}{ccr}\text { No. of Pages } & \text { Rate } & N \\ 1 & 27.7 \% & 202 \\ 2 & 33.5 \% & 943 \\ 3 & 36.6 \% & 883 \\ 4 & 37.9 \% & 742 \\ 5 & 42.6 \% & 545 \\ 6-10 & 42.0 \% & 1240 \\ 11-15 & 41.6 \% & 296 \\ 16-59 & 52.5 \% & 158\end{array}$

11. Reversal Rates of States Grouped by Exercise of Discretion, 1940-1970

$\begin{array}{cc}\text { No discretion } & \text { Rate } \\ \text { R.I. } & 33.3 \\ \text { Me. } & 28.7 \\ \text { S.D. } & 40.2 \\ \text { Idaho } & 31.7 \\ \text { Nev. } & 25.7\end{array}$




\section{Little discretion}

III.

Mich.

Minn.

Kan.

Ala.

N.C.

Ore.

Substantial discretion

Cal.

N.J.

Tenn.

W. Va.
33.3

31.7

38.1

24.8

30.3

47.2

39.8

44.2

40.5

40.8

67.3 